\title{
Public Opinion and Framing Effects of Argentine Foreign Policy Toward Brazil: Evidence from a Survey Experiment in Urban Centers in Argentina*
}

Carola Lustig(1) and Tomás Olego(2)**

\section{Abstract}

Studies about the relationship between public opinion and foreign policy are rare in Latin America as civic participation in these issues is a recent phenomenon. The following research explores the general perception of Argentine citizens about the orientation of foreign policy towards Brazil. Also, it explores the effects of information and its influence on citizens. In particular, it studies the psychotropic and socio-tropic attitudes of Argentinians about foreign policy toward Brazil. Based on a survey experiment, the research evaluates the impact of economic and political information (framing-effects) on the public's opinion of foreign policy (dependent variable). The experimental treatment was designed in an ordinal model by providing different pieces of information. The experiment also introduces 'Citizen Perception' as a covariate generated from a summation index with the scores of two variables (Preference for the actions of Argentina toward Brazil and the Position of Brazil in a charted

\footnotetext{
* Received on 01 November 2015 and approved for publication on 31 March 2016.

** (1) University of San Martín, Buenos Aires, Argentina, carolamlustig@gmail.com; (2) University of San Martín, Buenos Aires, Argentina, olegotomas@gmail.com.
} 


\section{Carola Lustig and Tomás Olego}

preference of potential investor countries). The results show that the previous ideological bias is very significant and that the effects of information reinforce it. The work was run as part of a survey conducted by the Instituto PASCAL Universidad Nacional de San Martín, in Argentina's major urban centres during 2015.

Keywords: Latin America; Public Opinion; Foreign Policy; Argentina; Brazil.

A consensus lasted until recently concerning the imperviousness of Latin America's foreign policy to social demands and public opinion. The politicisation of foreign affairs is recent. This implies that citizens increasingly learn more about foreign policy and, for this reason, it becomes a public policy as much for discussion as for public scrutiny. The effects of information on this public policy should be studied.

Studies of Brazilian foreign policy in respect of the South American region have proliferated in the last three decades. The literature that analyses the emergence of the middle powers and regional powers, and their relationships with their neighbours, has not agreed on a single definition of its nature (Malamud 2011). Some authors describe these countries as intermediate powers (Brun and Muxagato 2012; Flemes 2007; Soares de Lima 2007; Hurrell 2000; Jordaan 2003; Keohane 1969) or emergent powers (Almeida 2004; Hurrell 2009; Schirm 2010); others as emerging middle powers or regional powers (Lara 2012), or hegemonic consensual leaders (Burges 2006, 2008), or without followers (Malamud 2011; Schirm 2010).

There are few empirical studies that have analysed the reactions and views of neighbouring countries concerning Brazil's politics. Russell and Tokatlián (2002) made a theoretical work about Argentina's vision related to the ranking of Brazil's international integration. The authors used the theoretical contributions of structural realism, balance of power and constructivism to classify the different stages in the relationship between both countries. The 
conclusion was that this relationship was, throughout the twentieth century, never of absolute enmity but of strong rivalry with some friendly aspects.

Recently, Malamud (2011) shows how Brazil does not have a leading role in South America. On the contrary, there is a growing mismatch between the regional and the global performance of Brazilian foreign policy related to regional power rivalries and a relative paucity of resources. Also, Flemes and Wehner (2013) conducted a theoretical classification of the reactions of the secondary powers of Argentina, Chile, Colombia and Venezuela vis-à-vis Brazil's influence as a regional power. In recent years, Argentina has maintained a competitive partnership and a soft balancing with Brazil due to their historically high level of competition as equals but with increasing asymmetries. Likewise, the Argentine Council for International Relations (Consejo Argentino para las Relaciones Internacionales) (CARI) has, since 1998, conducted research, every four years, about Argentine public opinion of its foreign policy. It analyses, among other topics, the opinion of the population in general and the points of view of expert leaders concerning the improvement of bilateral relations. Brazil appears as the main country with which Argentina should always have strong and close relations, but this view is much firmer among expert leaders than among the population at large.

However, these variations in the Argentine perception of Brazil have never been measured, nor the effects that information can have on the Argentine perception of Brazil. What is the state of Argentine public opinion toward Brazilian foreign policy? This empirical survey experiment, developed by Instituto Pascal Universidad Nacional de San Martín, allows us to analyse these variations. The survey utilises Argentina's main urban centres as a variable, and permits us to verify individual attitudes with different information regarding both the perception of Argentine public opinion about Brazil and possible 


\section{Carola Lustig and Tomás Olego}

issue framing related to foreign policy. In short, this experiment answers two questions: first, what is the general perception of Argentine citizens about the orientation of foreign policy toward Brazil nowadays and, secondly, what are the effects that information can have on citizens concerning foreign policy toward Brazil?

This paper has five sections. The first section analyses the literature on public opinion, framing effects and foreign policy. Section two presents the theoretical debate on survey experiment about individual attitudes and socio-tropic motivations toward foreign policy. Section three examines the historical context of the relationship between Brazil and Argentina and the hypothesis of the experiment. Section four shows the results from the survey experiment. The last section presents the conclusions.

\section{Public opinion, framing effects and foreign policy in Latin America}

Throughout the twentieth century, the way in which the public is influenced by information has been the subject of studies. The written assignments about the relationship between the media and the public made their first steps with research on the mass media. Since the early twentieth century until the 1930s, the prevailing view was that the media exerted a powerful influence on public opinion. The 'Hypodermic Needle Theory', expressed in Harold Lasswell's studies (1927) concerning advertisements during the First World War, concluded that the effects of information and propaganda are direct (stimulation - answer), without any instance of intermediation, and that they generate immediate acceptance from the receptors to different political plans. In sum, the press can easily manipulate the public. 
However, by the 1960s, with the emergence of the founding fathers of the agenda-setting tradition of research (Cohen, the Lang couple and their disciples of Chapel Hill School, McCombs and Shaw), new inconsistencies undermined the theory of 'deviation to the hypodermic needle effect theory' (e.g. Lazarsfeld, Berelson and Gaudet 1944; Berelson, Lazarsfeld and McPhee 1954; Klapper 1960). This theory upholds that the media is not omnipotent in public opinion, nor in the behaviour of voters, but that it sets the public agenda. Therefore, the media does not form opinion but establishes the matters on which we, the public, must have an opinion. This would imply that when people vote they have already made up their minds on many issues, but that the media is the machine that serves as an intermediary to define on which issues they should take a position. Regarding the rationality of the electoral choice, the literature in Political Science that has considered the effects of information on people has focused on analysing the use of information as a determinant in voting behaviour.

Analysis concerning the relationship between public opinion and foreign policy was widespread in the USA in the 1960s. The main question then was if the so-called 'public' had anything coherent enough to be called 'attitudes' toward foreign policy (Aldrich et al. 2006).

One of Bernard Cohen's pioneering academic works (1956) emphasised that the press had become an integral factor in the foreign policy-making process in the USA: not as a lobbyist but as the 'bloodstream' that enables the conjunction and compression of foreign policy, by structuring some images towards public opinion. The author welcomed the popularisation of international relations due to increasing levels of information on the part of the public in general. On the one hand, the author found more demand from foreign policy observers to better cover these issues in order to improve levels of interest, while on the other hand, he was concerned 


\section{Carola Lustig and Tomás Olego}

about the popularisation of international relations and its corresponding decline in the effectiveness of such public policy. Cohen argues that journalists have influence in shaping this policy: the press decides the contextual framework and the priority levels and importance of the issues. The media does not tell people 'what to think' but 'what to think about'. Cohen examines the different functions that the press performs in the field of foreign policy formulation. The press communicates, interprets, promotes and installs certain issues related to foreign policy. From these functions, Cohen affirms:

[T] he press is helping to create or shape the outlines of foreign policy issues in the minds of the general public, of organised groups, and of government officials more or less remote or removed from these particular issues; and almost at the same time is helping to provide policy-makers with some image of "public opinion" on the issues thus structured (Cohen 1956: 132).

Bernard Cohen's main contribution to this debate is to warn that the media is not limited simply to communication, but that it frames, contextualises, chooses, constructs a topic and can even precipitate policy commitments or diplomatic actions by publicising matters (Cohen 1956: 132). In short, the media acts politically by creating a cartography of the mind (map-making) by which public opinion builds and delineates its own cognitive maps. The purpose is not to retreat into press responsibility about its intervention in foreign affairs but to highlight the danger of under-estimating its role as a simple objective broadcaster of political events.

Aldrich et al. (2006) also call attention to the important role that foreign policy issues can have in public opinion and thus for electoral campaigns. The research shows that the public can be strongly interested in foreign affairs. The authors affirm that the public holds 
reasonably sensible and nuanced views, and that these help shape their political views that, in turn, help shape and constrain foreign policy making.

However, the literature also wonders what the components are of public opinion that the press would influence. Is it formed by the opinion of experts on certain issues, or is it the view that belongs to ordinary citizens? Is it made of the elites or of the masses? Is it built bottom-up or top-down? Can public opinion be manipulated? With a data set on foreign policy opinion changes in the USA from the 1930s to the 1980s, Shapiro and Page (1988) came to the conclusion that public opinion on American foreign policy was neither volatile nor capricious, but rational. With this quantitative analysis, authors became opposed to a widespread pessimistic view about public opinion, especially when it came to foreign policy. Gabriel Almond's 'mood theory' (1950) stated that public opinion is normally indifferent to foreign policy and responds only to immediate threats. Thus, it is difficult for the public to contribute very constructively to policy deliberations. Walter Lippmann (1956) criticised policymakers who paid too much attention to public opinion. Lippmann saw the public as an irrational and dangerous force in foreign policy. Bernard Cohen (1956) indicated that the mass public had little capacity to contribute anything substantial to a dialogue about foreign policy.

In contrast to the pessimistic 'Almond-Lippmann consensus', the Vietnam experience permitted American scholars to have access to large public opinion datasets with questions about foreign policy (Aldrich et al. 2006: 479). This began to contradict mainstream ideas that public opinion was irrational. Shapiro and Page (1988) were the first authors to present direct empirical evidence. They showed that public opinion deserved a better mark and that it was not as indifferent or manageable as revealed, if we arrived at an understanding of public opinion as individual behaviour with 


\section{Carola Lustig and Tomás Olego}

aggregated collective public opinion data. The public is not volatile in its opinions, but information bias or systematic misinformation can have deep effects on public opinion. In short, the relationship between American public opinion and foreign policy is not constructed top-down because it is not as volatile or irrational as it is affirmed, but the public's preferences may be influenced by a context of permanent misinformation.

Thomas Risse-Kappen (1991) also reviewed the two static models bottom-up, top-down - by considering masses or elites as unitary actors:

While certain segments of the public may be manipulated by government propaganda, others may resist efforts to influence them. One should at least distinguish between (1) mass public opinion, (2) the attentive public, which has a general interest in politics, and (3) issue publics, which are particularly attentive to specific questions. Moreover, elites are themselves frequently divided, and different segments of the elite try to convince the general public of their respective viewpoints (Risse-Kappen 1991: 482).

The author analysed the impact of both social actors and public opinion on foreign policy in liberal democracies. Why do States, similar in size and resources, respond in different ways to the conditions and restrictions of the international system? His research showed that the impact of public opinion on foreign policy does not depend on the topics involved but on the domestic structure and on the construction process of the coalition support on those matters. The research analysed the impact of public opinion in four liberal democracies with different domestic structures: the USA, France, West Germany and Japan. The different political institutions, 
political strategies and societal structures led to different decisions and to different foreign policy layouts.

This long-established academic tradition in the USA on the relationship between public opinion and foreign policy is now moving to emergent democracies. Regarding Latin America, some studies have been conducted in the Brazilian academic field. This event, in the academic field, corresponds to the politicisation of foreign policy. The historic imperviousness of formulating foreign policy related to social demands begins to be called into question in Latin America. Several recent studies report the opening of foreign ministries regarding citizenship and about the citizens' larger interest and information in this area.

Carlos Faria (2008) presents the reasons for the isolation between public opinion and foreign policy in Brazil: (a) the constitutional structure that gives great autonomy to the Executive relegated to a marginal position to Congress; (b) the imperial character of Brazilian presidentialism; (c) the kind of development of import substitution that generated a great introversion in economic and political processes; (d) the adaptive nature of the Brazilian diplomacy; and, (e) the early professionalisation of the Brazilian diplomatic corps (Faria 2008: 81). The lack of interest in the interaction between society and diplomacy can also be attributed to a low demand on the part of Brazilian society for greater accountability and responsibility of State agents (Faria 2008: 93). However, this isolation of Brazilian foreign policy from its citizens that was mutating from the 1990s and allowed some interaction between public opinion and foreign policy, has begun to be of interest to the Brazilian Academy.

Leticia Pinheiro (2009) carried out an analysis of Brazil's foreign policy and showed social agents' diversification. The author argued that, traditionally, the Executive branch had predominantly exercised the conduct of foreign policy: in some cases through the 


\section{Carola Lustig and Tomás Olego}

Ministry of Foreign Relations and in others through the direct involvement of the President. She expressed the view that 'the personal conduct of foreign policy by the President of the Republicthe so-called 'presidential diplomacy' - could be understood as a particular response to the 'historical Itamaraty autonomous action' (Pinheiro 2009: 18). The defence and economic ministries, the so-called historical rivals of Itamaraty, were also involved as representatives of the Executive branch. But the horizontal de-centralisation of foreign policy formulation occurs only from the economic liberalisation of the 1990s, the intensification of the globalisation process and the end of the Cold War. The economic liberalisation produced winners and losers in relation to an external phenomenon; the globalisation process enhanced the impact of external events concerning internal issues, and the end of the Cold War freed the ideology and diversified the agenda of matters to be solved by States. This horizontal de-centralisation was reflected in the fact that each Ministry had an international consultative area to respond to every specialisation and also by the generation of an intensification of diplomatic sub-national units.

Belém Lopes (2011) also documented the process of democratisation of Brazil's foreign policy and the consequent positive growth in the relationship between citizens and the Chancellor's office. With the return of democracy, the speeches of the State's representatives at the UN register an attempt to portray a new international image for Brazil. Public access to historical Itamaraty archives - which allowed the opening of foreign policy was regulated in 1992. Thus, the foreign affairs ministers of Brazil, appointed during the democratic period, recognised the discrepancy between the democratisation of the country's public policy and the delay in opening foreign policy to society. However, the process of openness was a response more to the demand or need to promote a political legitimacy and a democratic image to the world than to a real motivation to share the decision-making power with society. 
The expansion celebrated by both the participation and the inclusion of new groups in the debate on Brazil's trade policy did not automatically translate into a proportional increment in the transparency level and in the influence of these groups regarding the definition and implementation of the policy (Belém Lopes 2011: 73).

Overall, few empirical studies have been made in Argentina linking the multiple relationship between public opinion, framing effects and foreign policy. The Argentine Council for International Relations publishes a report, referred to as the Argentine Public Opinion on Foreign Policy and Defence ${ }^{1}$ every four or five years. It shows the Argentine - general public and opinion leaders - level of interest in information about foreign policy and how they perceive the region.

The last report (2015) shows that public opinion follows international news always or with high frequency (58.5\%) and that a very high percentage $(69.7 \%)$ comes from high-class sectors. Also, the report registers that public opinion believes that Brazil will have a stronger presence in the international domain (38.3\% for public and $43 \%$ for qualified experts) followed by Argentina (30.2\% for public and $39 \%$ for qualified experts). To the question about which countries should Argentina prioritise in its strategy of international policy, public opinion prefers Latin American countries (28.7\%) followed by Brazil (18.8\%). For opinion leaders, Argentina should prioritise its relationship with Brazil (30\%), followed by Latin American countries (24\%) and then the USA (20\%).

The 2010 report registered that Argentines perceive the international leadership of its regional partner, Brazil, as the only relevant one in the family of nations. Although there is not a sharply defined preference, the USA is the favourite for the general population when 


\section{Carola Lustig and Tomás Olego}

choosing the consolidation of bilateral relations (18\%), followed by Brazil (7\%) and Latin American countries (7\%). Regarding the level of interest about foreign affairs information, $13.4 \%$ of the general population keep informed about international politics on an on-going basis while $32 \%$ do it with some frequency. Between 2010 and 2015, therefore, the reports confirm a considerable increase in the number of movers and shakers in society and in the size of the general population who think that it is better to have balanced regional powers rather than having a system led by the UN for the maintenance of world peace. Also, $60.4 \%$ of the population believe that the relationship with Brazil has improved in recent years.

Likewise, Argentine specialists from several universities ${ }^{2}$ published a survey (UTDT-UdeSA 2015) showing that Brazil and Uruguay are the regional countries that appear to be closest to Argentina's heart: between $60 \%$ and $63 \%$ feel that there is a good relationship with both countries. Argentines place the greatest confidence in Brazil as Latin America's regional leader, while Chile and Mexico are the least trusted as regional leaders. Meanwhile, Germany, Uruguay, Spain, China and Brazil have a favourable image in the eyes of Argentines, whereas Turkey, South Africa, Iran, Israel and India attract the least favourable opinion. In both cases, information proceeds from surveys without panel data.

\section{Socio-tropic politics versus individual attitudes toward foreign policy}

In order to evaluate how information affects public opinion, socio-tropic politics versus individual attitudes toward foreign policy must be discussed. This debate is of interest for the research as we hypothesise that the prior beliefs or socialisation are stronger determinants of the position toward Brazil than individual motivations. 
Most recent empirical studies (Ardanaz, Murillo and Pinto 2013; Hiscox 2002, 2006) on the relationship between public opinion and foreign policy have been made in the USA and assess the political economy of trade and the support for globalisation. All these investigations are torn between individual motivations supporting trade policies and socio-tropic previous perceptions or perspectives. This academic debate is important because it finds that the prior beliefs or socialisation are stronger determinants of the position toward Brazil than individual motivations. This will be discussed briefly in this section.

An important group of researchers (Stolper and Samuelson 1941; Leamer 1984) has analysed survey data to show that less-educated, blue-collar workers fear more the distributional effects of globalisation than other individual variables. This research supports the Samuelson (1941) theorem about the income effects of trade that predicts that trade openness benefits those owning factors of production with which their economy is relatively well endowed (those with high skill levels in the advanced economies) while hurting others (low-skilled and unskilled workers).

But this positive relationship between education and support for trade liberalisation might also - and perhaps primarily - reflect the fact that more educated respondents tend to be more exposed to economic ideas about the overall efficiency gains for the national economy associated with greater trade openness, and tend to be less prone to nationalist and anti-foreign sentiments often linked to protectionism (Hainmueller and Hiscox 2006: 470). Increased education tends to socialise students to have more tolerant, cosmopolitan views of the world. So, higher levels of education show a positive relation to trade policy preferences not because of personal skills or the industrial sector in which the person works, but because of the alternative ideational and cultural accounts that a higher education implies. Hiscox and Hainmueller (2006) get to the 


\section{Carola Lustig and Tomás Olego}

conclusion showing that the impact of education on attitudes toward trade is almost identical among respondents currently in the active labour force and among those who are not (even those who are retired).

Mansfield and Mutz (2009) also refute the idea that trade preferences are shaped by how trade affects an individual's income. This thesis argues that trade preferences are affected primarily by a person's skills, or depend on the industry in which the person works. Using data from two national surveys, the authors conclude that the only significant variable affecting Individual trade preferences is based on education but, as Hiscox and Hainmueller discover, socio-tropic reasons are more than individual positions. They find strong evidence that trade attitudes are guided less by material self-interest than by perceptions of how the US economy as a whole is affected by trade. The authors look to determine if trade is an exception in which personal experiences are successfully politicised. Alternatively, if attitudes about trade are formed in a manner similar to attitudes about domestic economic domains, such as unemployment, the trade policy preferences will be based on how people believe a policy affects the country collectively rather than by narrowly defined self-interest (Mansfield and Mutz 2009: 426).

Other research has examined the interaction between public opinion and foreign policy through survey experiments in order to measure framing effects:

Public opinion scholars show how framing effects can shape the perception of individual utility, thus calling into question the material origins of individual policy preferences, and focusing instead on how socialisation, ideological bias, and elite consensus shape how individuals process policy preferences. Several studies show that individuals' sensitivity to issue framing depends on their 
prior beliefs, which are generated by strongly held values and cognitive abilities (Ardanaz, Murillo and Pinto 2013: 415).

The emphasis on socialisation, ideological leanings, education, and socio-tropic perceptions has relegated material interests to a secondary role in the most recent literature on trade policy preferences, by focusing the debate on material motivations as an alternative process affecting individuals' susceptibility to framing effects in public opinion surveys. We aim to bring material interests back into the debate by focusing on material motivations as an alternative process affecting individuals' susceptibility to framing effects in public opinion surveys.

\section{Historical framework and the theoretical debate on survey experiment}

The relationship between Argentina and Brazil has been fluctuating in recent decades. Brazil has become an emerging power, only brought into question nowadays. This has meant a significant switch in Latin America's power equation and therefore it has produced changes in the relationship with its neighbours, particularly with its strategic historical ally: Argentina. After Argentina's institutional economic political crisis in 2001, Brazil became its main ally, as it was one of the few countries that financially had helped the country when the international financial markets abandoned it. But this was also accompanied by a growing asymmetry between both countries at Argentina's expense. This is how Argentina changed from experiencing a period of pro-Brazilian euphoria - by thinking of this country as its strategic partner - to a gradual negative sentiment towards Brazil, by showing how difficult it is to maintain friendly ties with a nation with which it had competed for regional dominance for over a century (Tokatlián 2009). 


\section{Carola Lustig and Tomás Olego}

Within this context of Brazil's international growth, it is essential to know the opinion of the citizens of neighbouring countries regarding its foreign policy. As previously stated, this paper has two objectives. The first is to know today's general perception of Argentine citizens about Brazil. The second is to analyse the effects of information on citizens concerning foreign policy. For that, we designed a general survey related to Argentines' perceptions of Brazil by building an index of 'Brazilianness' that it is also used as a variable control. Then we made an experiment using four different processes.

There is an in-depth discussion concerning the methodological difficulties in carrying out statistical analysis of surveys, in particular, the dangers of causal inference, selection bias, spurious correlation, mutual causality (Gaines, Kuklinski and Quirk 2006). The panels where information is collected from the same individuals, in different waves, enables longitudinal analysis to determine which variables generate a change to bring about more accurate inferences. Likewise, it is very expensive to maintain survey panels and it is difficult to implement them. They can also induce changes in the attitudes of those being polled as they are always the same.

The experiments allow us to overcome some of the above-mentioned problems. We can distinguish causes from effects by assigning questions and different treatments to different control groups. Political scientists use experiments to identify how people make decisions and respond to the objectives of the real world to understand politics (Gaines, Kuklinski and Quirk 2006: 1-20). These same authors have described the problems that may result in the experiments.

First, the order of the questions and the order of the words used in the survey can influence the response ${ }^{3}$. Secondly, the experiments do not take into consideration the effect of time. Perhaps the effect of information on a person's position lasts a few minutes after having been asked the question, and then the person returns to their 'home 
position'. Thirdly, as it is customarily a single wave, the experiments may take as irrelevant those topics that are pertinent for the real world, and maybe the information provided in this wave is not enough to measure a relevant question. Fourthly, the experiments can save the problem of endogeneity, typical of non-experimental surveys when designating dependent and independent variables. However, the problem with this is that it requires a causality relationship by default that may be weak or wrong. Finally, non-experimental surveys do not include control groups.

The research proposed in this paper analyses the relationship between information and opinion on foreign policy, in particular the perception of Argentine public opinion concerning Brazil. It has been based on two assumptions. The first hypothesis is that Argentina's public opinion related to its neighbouring country is negative because of their historical rivalry and, nowadays, the superiority of Brazil. This hypothesis is rejected through the construction of an index 'Perception towards Brazil' where is confirmed a very high preference on the part of Argentines for Brazil compared to other countries. The second hypothesis, with which we will work, is that the effects of information related to foreign policy are not powerful enough to alter previous perceptions.

\section{The Argentina Survey Experiment in Urban Centre: hypothesis and results}

As previously stated, this paper has two objectives. One is to know today's general perception of Argentine citizens about Brazil. The second is to analyse what the effects are of information on citizens concerning foreign policy. Continuing the investigation line of Mansfield and Mutz (2009) we will test for socio tropic motivations for foreign affairs preferences and we will see how information that 


\section{Carola Lustig and Tomás Olego}

implies societal consequences interacts with ideological bias and/or preconceptions.

To do this, two nested hypotheses in terms of their complexity were tested:

- H_I: positive information generates a positive Opinion. (i.e., the relationship between Opinion and Information is a monotone increasing function)

- H_II: The relationship between Opinion and Information is conditioned by Preconceptions (i.e., the relationship between Opinion and Information is a monotone increasing/decreasing function conditioned by positive/negative Preconceptions).

If $\mathrm{H} \_$II was to be true, then the sign of Public Opinion should be stable to small information shocks.

The experiment was carried as a face-to-face survey in which respondents were randomly assigned to one of the four experimental groups. The experimental stimulus was administrated in the middle of the questionnaire as information about the bilateral relationship that could lead to a positive or negative consequence for Argentina. The objective was to model the response surface to variations of information balance (from negative to positive). Therefore, the experimental treatment was designed in an ordinal fashion and it represents the scale, from negative to positive, of the impact for Argentina as a whole:

Group 1: (-)

In May 2012, Vale, the largest private mining company in Brazil, confirmed an investment of US\$1000m in a potassium deposit in Mendoza and in another of unconventional gas in Neuquen Province. In addition, in 2013, Brazil was the largest recipient of foreign investments totalling US\$60 billion, one third of all investments received in the region. 
Group 2: (-)

In May 2012, Vale, the largest private mining company in Brazil, confirmed an investment of US\$1000m in a potassium deposit in Mendoza and in another unconventional gas in Neuquen Province. In addition, in 2013, Brazil was the largest recipient of foreign investments totalling US\$ 60 billion, one third of all investments received in the region. Likewise, in September 2014, Brazil supported Argentina in the United Nations Human Rights Council Resolution on the Condemnation of the activities of vulture funds.

Group 3: (+)

In May 2012, Vale, the largest private mining company in Brazil, confirmed an investment of US\$1000m in a potassium deposit in Mendoza and in another unconventional gas in Neuquen Province.

Group 4: (++)

In May 2012, Vale, the largest private mining company in Brazil, confirmed an investment of US\$1000m in a potassium deposit in Mendoza and in another unconventional gas in Neuquen. Likewise, in September 2014, Brazil supported Argentina in the United Nations Human Rights Council Resolution on the Condemnation of the activities of vulture funds.

The response variable was measured also as ordinal: What perception do you have about the economic relationship between Argentina and Brazil?

(*) It is negative for the Argentine economy?

(*) It is negative for certain sectors of the Argentine economy?

(*) It does not affect the performance of the Argentine economy

(*) It is positive for certain sectors of the Argentine economy

(*) It is positive for the Argentine economy?

Covariate: Citizen Perception concerning Brazil Index (preconception) 


\section{Carola Lustig and Tomás Olego}

The proxy for preconception was a summation index generated with the scores of two questionnaire variables:

* Using the scores, the index was generated as:

1 - ( Question_I - 1 ) / 5 - ( Question_II - 1 )/ 4

which is the sum of the two normalised variables, centred at zero.

* Level of measurement: Interval [-1,1]

* While the first question represented an economic dimension, the second one was political

* To avoid possible contamination, both variables were measured at the beginning of the survey

Question I: Position of Brazil in a charted preference of potential investor countries

*** If some of the major private and public companies in Argentina would be in the hands of foreign capitals, you would like them to be in hands of... What order? [ORDER COUNTRIES FROM 1 TO 6]

(*) USA

(*) England

(*) Brazil

(*) China

(*) Mexico

(*) Spain

Question II: Preference in the actions of the Argentine State towards Brazil

Position of Brazil in a charted preference of potential investors countries

*** Here we will ask you about the priorities that the government should undertake in foreign affairs. Please tell us by what measure you believe that the Argentine government should approach its relationship towards Brazil

(*) Much more

(*) Some more

(*) Stay 
(*) Step aside

(*) Break relations

\section{Sampling design and the randomisation process}

The population under study were Argentine citizens, over the age of 18 , and residing in the principal metropolitan areas (see Appendix Table A) from 10 December 2014 to 26 July 2015. The survey was designed as a random multi-stage sample. Strata were defined for each metropolitan area and proportional allocation to population size was used. Within each stratum, clusters of blocks were defined and randomly sampled with probability proportional to population density. The final stage used systematic sampling of houses. Once the sampling unit was reached, each pollster conducted the survey with a specific package of questionnaires. This package contained one of the four rotations for each questionnaire and was randomly assigned at the printing house.

\section{Descriptive results}

\section{Table 1}

Distribution of respondents by rotation and metropolitan area

\begin{tabular}{lcccc}
\hline URBAN CENTRE & ROTATION I & ROTATION II & ROTATION III ROTATION IV \\
\hline CABA and GBA & 248 & 246 & 244 & 245 \\
Córdoba - Gran Córdoba & 246 & 232 & 216 & 243 \\
Tercer Cordón & 35 & 34 & 30 & 40 \\
Resistencia - Corrientes & 96 & 100 & 96 & 117 \\
Gran La Plata & 26 & 25 & 24 & 25 \\
Gran Mendoza & 167 & 166 & 163 & 173 \\
Paraná - Santa Fe & 54 & 52 & 54 & 63 \\
Rosario - Gran Rosario & 192 & 201 & 193 & 194 \\
Gran Tucumán & 92 & 83 & 69 & 97 \\
Alto Valle de Río Negro & 84 & 84 & 94 & 84 \\
\hline TOTAL & $\mathbf{1 2 4 0}$ & $\mathbf{1 2 2 3}$ & $\mathbf{1 1 8 3}$ & $\mathbf{1 2 8 1}$
\end{tabular}




\section{Carola Lustig and Tomás Olego}

Figure 1 and 2 show the results for Preconception and the response variable

Figure 1

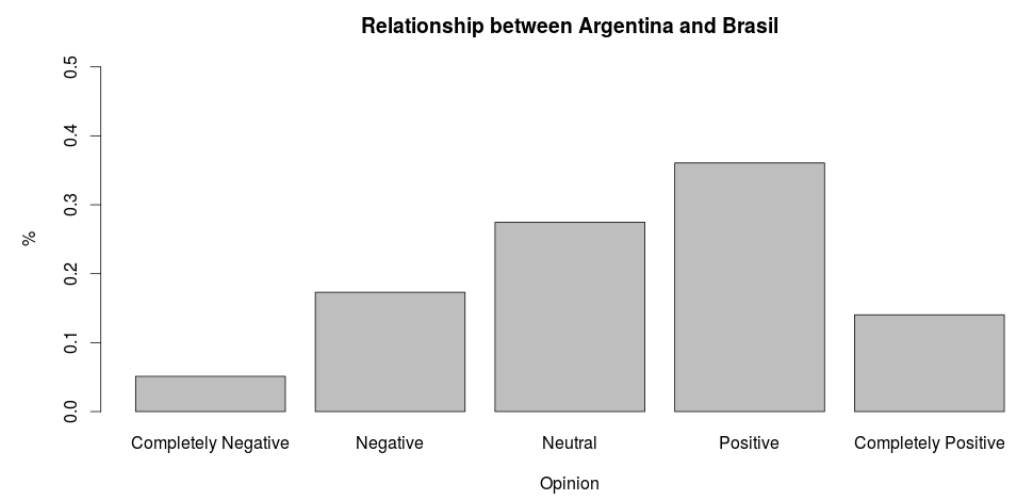

\section{Figure 2}

Histogram of Preconception Index

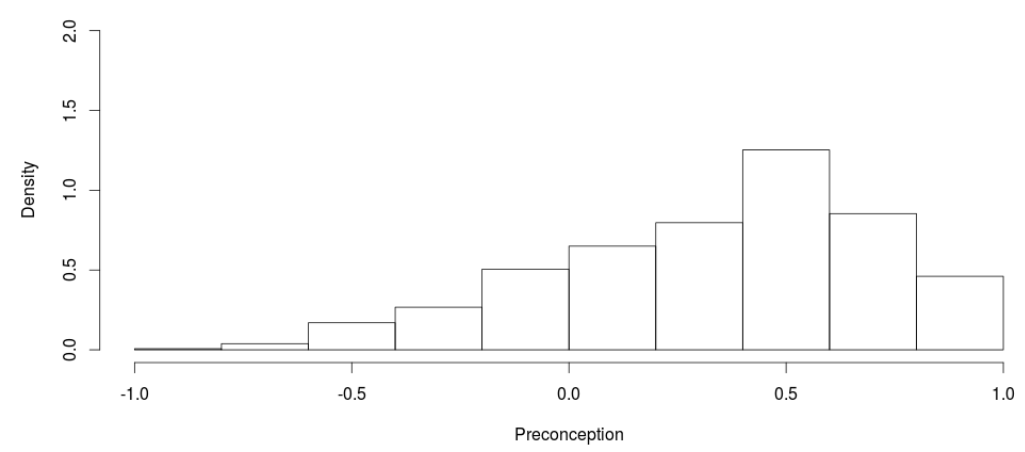

Covariate versus treatment

Table 2 and Figure 3 show the relationship between treatment and preconception. As the candidate covariate is not related to the treatment (Casella 2008), it can be incorporated to the model. 


\section{Figure 3}

Boxplot of Preconception by treatment

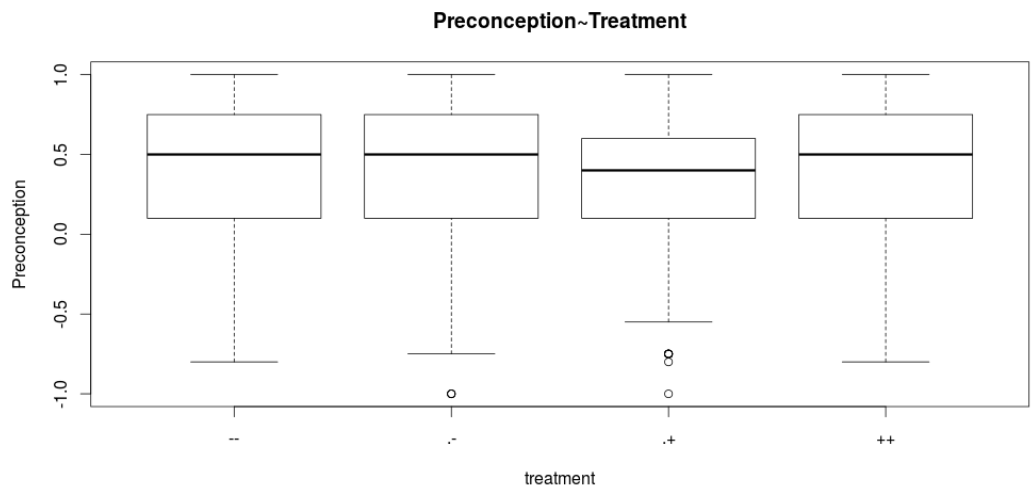

Table 2

\begin{tabular}{|l|c|c|c|c|}
\hline & \multicolumn{5}{|l|}{} \\
\hline Preconception & - & -- & + & ++ \\
\hline$[-1,-0.6]$ & 13 & 13 & 9 & 10 \\
\hline$(-0.6,-0.2]$ & 102 & 107 & 117 & 104 \\
\hline$(-0.2,0.2]$ & 275 & 290 & 292 & 281 \\
\hline$(0.2,0.6]$ & 523 & 497 & 471 & 528 \\
\hline$(0.6,1]$ & 327 & 316 & 294 & 358 \\
\hline
\end{tabular}

Spearman Correlation: 0.0065

Chi-square $=9.77$, p_value $=0.6361$, Cramer's $\vee 0.0257$

\section{Analysis}

The experiment was analysed like an ordinal regression problem using an ordinal cumulative link model. Cumulative logit was used as the link function and the intercept was defined as the variable threshold. Due to the fact that the stimulus was also ordinal, it was codified using orthogonal polynomials. Finally, the interacting variable was treated as numerical. 


\section{Carola Lustig and Tomás Olego}

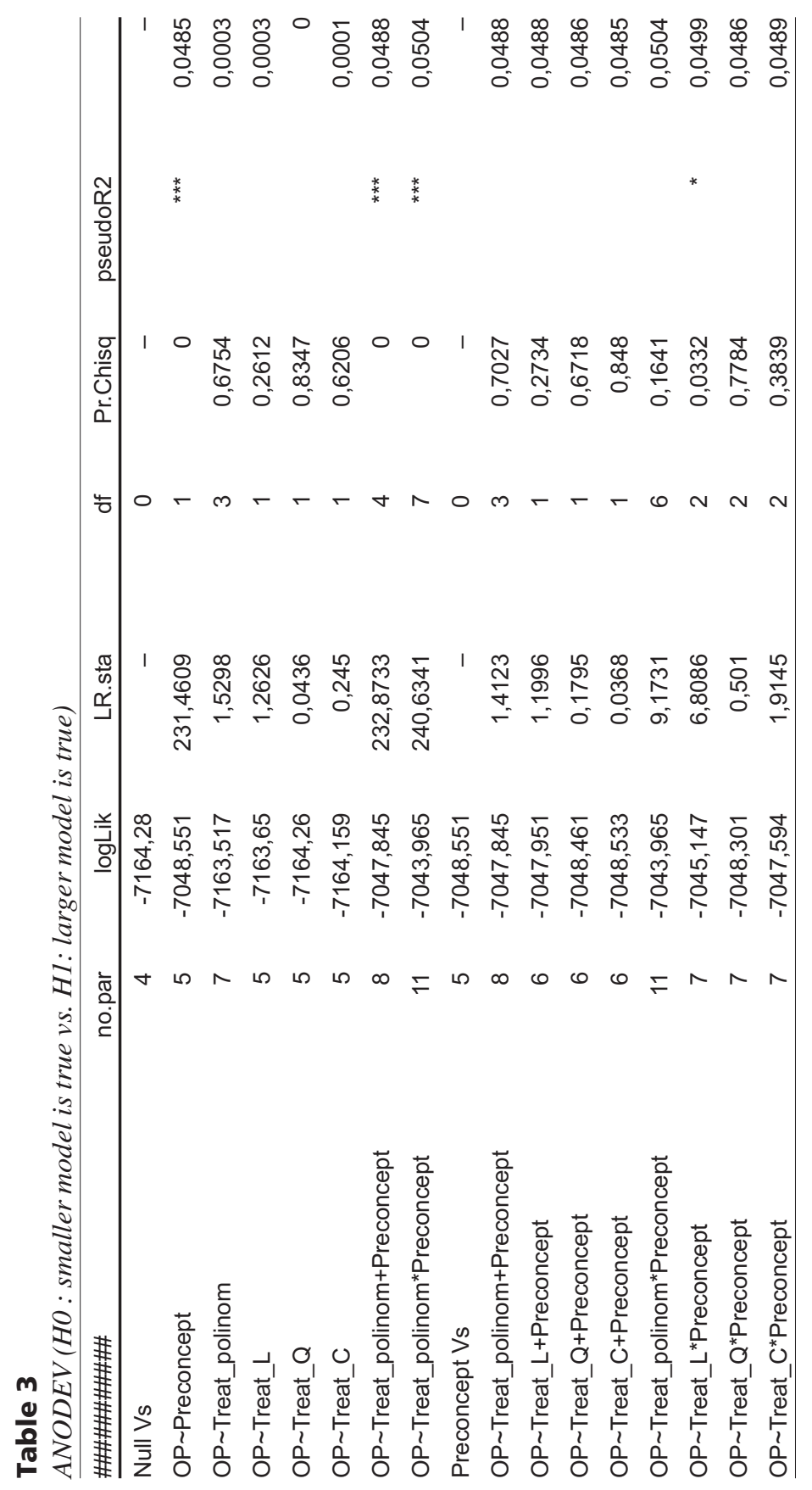


Neoliberal Crisis, Social Demands, and

Foreign Policy in Kirchnerist Argentina

According to Table 3, there is significant evidence in favour of H_II and a linear influence of the treatment. Table 4 also presents more evidence of a reduced linear variable interaction model.

\section{Table 4}

Summary or model OP Treat_Polinom*Preconcept

\begin{tabular}{|c|c|c|c|c|}
\hline \multicolumn{5}{|l|}{ Coefficients } \\
\hline & Estimate & Std.Error & zvalue & $\operatorname{Pr}(>|z|)$ \\
\hline Preconcept & 0.994379 & 0.065739 & 15126 & $<2 \mathrm{e}-16^{* * *}$ \\
\hline Treat_L & 0.170938 & 0.070747 & 2416 & $0.0157^{*}$ \\
\hline Treat_Q & 0.007489 & 0.070101 & 107 & 0.9149 \\
\hline Treat_C & -0.050692 & 0.069498 & -729 & 0.4658 \\
\hline Preconcept:Treat_L & -0.304249 & 0.128165 & -2374 & $0.0176^{*}$ \\
\hline Preconcept:Treat_Q & -0.072645 & 0.128742 & -564 & 0.5726 \\
\hline Preconcept:Treat_C & 0.175256 & 0.129385 & 1355 & 0.1756 \\
\hline \multicolumn{5}{|c|}{ 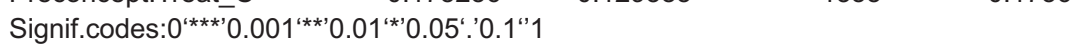 } \\
\hline \multicolumn{5}{|c|}{ Threshold coefficients: } \\
\hline & Estimate & Std.Error & zvalue & \\
\hline $1 \mid 2$ & -2.62588 & 0.06726 & -39043 & \\
\hline $2 \mid 3$ & -0.91594 & 0.04013 & -22825 & \\
\hline $3 \mid 4$ & 0.36900 & 0.03797 & 9718 & \\
\hline $4 \mid 5$ & 2.24349 & 0.05091 & 44070 & \\
\hline
\end{tabular}

To review this hypothesis, multiple testing was carried out controlling False Discovery Rate (FDR) with the Benjamini-Hochberg procedure at alpha $=0.05$ (Table 5). Results indicate that threshold coefficients are distinct, interaction significant and that only the linear trend in preconceptions stands.

\section{Table 5}

Summary or Multiple Testing using FDR at alpha $=.05$ with permutation test to construct empirical p.values

\begin{tabular}{lrrr}
\hline Test & Value & p.values & alpha_cut \\
\hline $1|2-2| 3=0$ & 1,709942021 & 0 & 0,005 \\
$2|3-3| 4=0$ & 1,284937496 & 0 & 0,01 \\
$3|4-4| 5=0$ & 1,874496796 & 0 & 0,015 \\
Perc $=0$ & 0,994379186 & 0 & 0,02 \\
Trat_L=0 & 0,170938152 & 0,01628 & 0,025 \\
Perc:Trat_L=0 & $-0,304249034$ & 0,01704 & 0,03 \\
Perc:Trat_C=0 & 0,17525642 & 0,17124 & 0,035 \\
Trat_C=0 & $-0,050692246$ & 0,46972 & 0,04 \\
Perc:Trat_Q $=0$ & $-0,072645283$ & 0,5638 & 0,045 \\
Trat_Q=0 & 0,007489337 & 0,915 & 0,05 \\
\hline
\end{tabular}




\section{Carola Lustig and Tomás Olego}

\section{Table 6}

Coefficients of OP Treat_L*Preconcept under non-parametric Bootstrap

\begin{tabular}{lrrr}
\hline Coef & Value & Lower $\mathbf{2 , 5 \%}$ & Upper $\mathbf{9 7 , 5 \%}$ \\
\hline $1 \mid 2$ & $-2,625$ & $-2,7649$ & $-2,4994$ \\
$2 \mid 3$ & $-0,9157$ & $-0,9948$ & $-0,8373$ \\
$3 \mid 4$ & 0,369 & 0,2949 & 0,4404 \\
$4 \mid 5$ & 2,2427 & 2,1448 & 2,3483 \\
Preconcept & 0,934 & 0,8652 & 1,1276 \\
Treat_L & 0,172 & 0,0257 & 0,3119 \\
Preconcept:Treat_L & $-0,3033$ & $-0,5558$ & $-0,0477$ \\
\hline
\end{tabular}

\section{Figure 4}

Cumulative Probability of Opinion

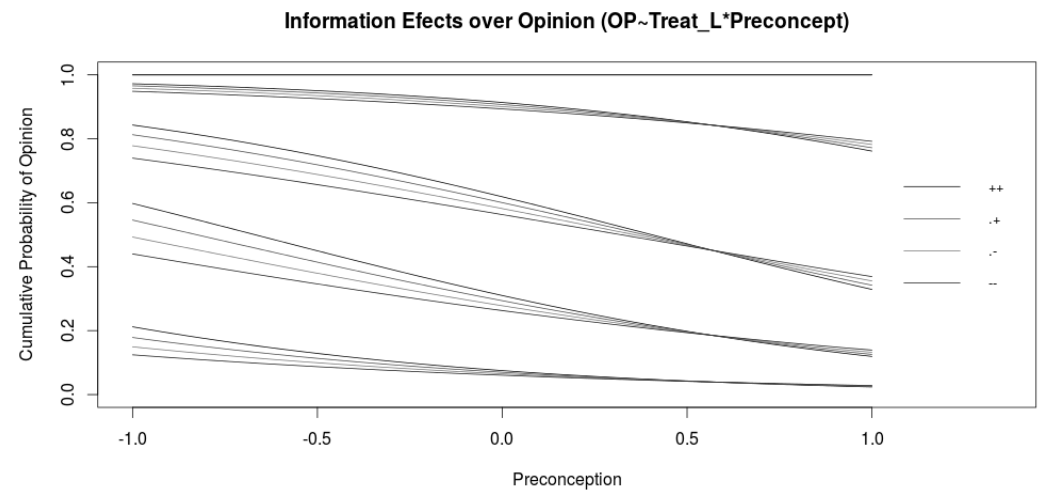

\section{Conclusion}

Brazil is the largest and most powerful leader in the South American region. Much has been studied about its foreign policy towards the region. Systemic factors and domestic variables have been explored in order to explain this foreign policy orientation. However, little has been done to understand the vision of its neighbours and their potential reactions. This article tries to move forward this line of research. What is Argentina's perception of Brazil? Is it possible to change this perception? 
Through a pilot survey of 4000 cases involving 4 different treatments, the effects of information on public opinion were measured. Also, with an intervening variable, the previous perception of Argentine citizens of Brazil was controlled. Work was based on two assumptions. The first hypothesis was that Argentine public opinion of its neighbouring country was negative. This hypothesis was rejected through the construction of an index of perception of Brazil where one can see a very high Argentinian preference for Brazil over other countries. The second hypothesis was that the effects of information on foreign policy are not powerful enough to alter previous perceptions. This hypothesis was confirmed.

The results show that prior beliefs held by the public about the neighbouring country are stronger than any kind of information offered. In this study we found that Argentine citizens have a 'high preference for Brazil' vis-à-vis other countries. The preference for Brazil does not decrease but increases, even in the face of negative information. It seems that people discard all items that are dissonant. This reminds us of the precepts of the theory of cognitive dissonance (Festinger 1957) which held that the dissonant elements are discarded by applying classical psychological strategies, such as rejecting what is dissonant.

Descriptive results indicate that, nowadays, the perception of Argentine citizens about Brazil is indeed positive. Experimental results indicate that the relationship between opinion and socio-tropic information is a monotone increasing/decreasing function conditioned by positive/negative preconceptions. This means that the result will depend upon previous preconceptions: negative information generates a negative response if previous preconceptions are negative. Conversely, negative information results in a positive response if previous preconceptions are positive. Moreover, negative preconceptions with a positive treatment 


\section{Carola Lustig and Tomás Olego}

generates a lower opinion than those with negative treatment. Therefore, it seems as though information is being used to reinforce previous preconceptions.

As has been anticipated, if H_II was to be true, then the sign of public opinion should be stable to small information shocks. This could mean that in international affairs, it might not be easy to change local public opinion as personal preconception plays a fundamental role. This poses an economic dilemma: how effective and efficient were Brazil's soft-politics in influencing Argentine citizens, traducing its support in public policy? Is the cost of soft-politics underestimated?

Of course, this work leaves some other questions that might be interesting to investigate in future studies. First, this article shows that the effects of information are not significant. However, this claim may be valid only for treatments in foreign policy. It remains to be seen whether the effects of information may be more significant in cases where other types of questions are asked. For this, one could compare the effect of this experiment on foreign policy with other experiments constructed in the same way that orbit other issues of public policy. This is the same as asking how they construct their views on foreign policy vis-à-vis citizens and other issues related to domestic politics or of a more direct and personal interest.

\section{References}

Almeida, Paulo Roberto. 2004. 'Uma política externa engajada: a diplomacia do governo Lula’. Revista Brasileira de Política Internacional 47 (1): 162-184.

Almond, Gabriel. 1977. The American People and Foreign Policy. New York: Harcourt Brace. 
Aldrich, John, Christopher Gelpi, Peter Feaver, Jason Reifler and Kristin Thompson Sharp. 2006. 'Foreign Policy and the Electoral Connection'. Annual Review of Political Science' 9: 477-502.

Ardanaz, Martin, María Victoria Murillo and Pablo M Pinto. 2013. 'Sensitivity to Issue Framing on Trade Policy Preferences: Evidence from Survey Experiment'. International Organization 67(02).

Belem Lopes, Dawisson. 2011. 'A política externa brasileira e a "circunstância democrática”: do silêncio respeitoso à politização ruidosa'. Rev. Bras. Polít. Int. 54 (1): 67-86.

Brun, Elodie and Bruno Muxagato. 2013. 'El proyecto internacional brasileño (2003-2010): Intenciones regionals y proyección global vía las relaciones Sur-Sur'. Anuario Americanista Europeo.

Burges, Sean. 2009. Brazilian Foreign Policy after the Cold War. Miami: University Press of Florida.

. 2006. 'Without Sticks or Carrots: Brazilian Leadership in South America During the Cardoso Era, 1992-2003'. Bulletin of Latin American Research 25 (1): 23-42.

Berelson, Bernard R, Paul F Lazarsfeld and William N McPhee. 1954. Voting. A study of opinión formation in a presidencial campaign. Chicago: The University of Chicago Press.

Casella, George. 2008. Statistical Design. Springer.com

Cohen, Bernard. 1956. 'The press and foreign policy in the United States'. Journal of International Affairs 10(2): 128-137.

Faria, Carlos. 2008. 'Public Opinion and foreign policy: insulation, politicization and reform in the production of Brazilian foreign policy'. Revista Brasileira de Politica International 51 (2): 80-97.

Festinger, Leon. 1957. A Theory of Cognitive Dissonance. Stanford, CA: Stanford University Press.

Flemes, Daniel. 2007. 'Emerging Middle Power's Soft Balancing Strategy: State and Perspectives of the IBSA Dialogue Forum'. GIGA Working Paper № 57. Available at SSRN: http://dx.doi.org/10.2139/ssrn.1007692. 


\section{Carola Lustig and Tomás Olego}

Flemes, Daniel and Leslie Wehner. 2013. 'Reacciones estratégicas en Sudamérica ante el ascenso de Brasil'. Foreign Affairs Latinoamérica 13 (4): 107-114.

Fraga, Rosendo and Pablo Asa. 2010. 'La opinion pública argentina sobre política exterior y defensa'. CARI, Consejo Argentino para las Relaciones Internacionales.

2015. 'La opinión pública argentina sobre política exterior y defensa'. CARI, Consejo Argentino para las Relaciones Internacionales.

Gaines, Brian J, James H Kuklinski and Paul J Quirk. 2006. 'The logic of the survey experiment re-examined'. Political Analysis Advance November 16.

Hainmueller, Jens and Michael J Hiscox. 2006. 'Learning to Love Globalization: Education and Individual Attitudes Toward International Trade'. International Organization 60 (2): 469-98.

Hiscox, Michael J. 2002. International Trade and Political Conflict: Commerce, Coalitions, and Mobillty. Princeton: Princeton University Press.

2006. 'Through a Glass and Darkly: Attitudes Toward International Trade and the Curious Effect of Issue Framing'. International Organization 60 (3): $755-80$.

. 2009. 'Brasil y la tormenta que se avecina'. Foreign Affairs Latinoamerica 9 (2).

2000. 'Some reflections on the role of intermediate powers in international institutions'. In Andrew Hurrell, Andrew F Cooper, Guadalupe González González, Ricardo Ubiraci Sennes and Srini Sitaraman. Paths to Power: Foreign Policy Strategies of Intermediate States. Working Paper no. 244. Washington, DC: Woodrow Wilson International Center.

Jordaan, Eduard. 2003. 'The Concept of a Middle Power in International Relations: Distinguishing Between Emerging and Traditional Middle Powers'. Politikon: South African Journal of Political Studies 30 (2): 165-181.

Klapper, Joseph T. [1960] 1974. Efectos de las comunicaciones de masas. Poder y limitaciones de los medios de difusión. Translated by José Aurelio Álvarez Remón. Madrid: Aguilar.

Keohane, Robert O. 1969. 'Lilliputian Dilemmas: Small States in International Politics'. International Organization 23 (2): 291-310. 
Public Opinion and Framing Effects of Argentine Foreign Policy Toward Brazil...

Lara, Ignacio. 2012. 'Potencialidades y límites de Brasil como potencia media emergente'. Anuario Americanista Europeo 2221-3872, NE 10: 53-72.

Lasswell, Harold. 1927. Propaganda Technique in the World War. New York: The Michigan University Press.

Lazarsfeld, Paul F, Bernard Berelson and Hazel Gaudet. 1944. The People's Choice. How the Voter Makes Up His Mind in a Presidential Campaign. New York: Columbia University Press.

Leamer, Edward E. 1984. Sources of International Comparative Advantage. Cambridge: MIT Press.

Lippmann, Walter. 1956. Public Opinion. New York: The Macmillan company.

Malamud, Andrés. 2011. 'A Leader Without Followers? The Growing Divergence Between the Regional and Global Performance of Brazilian Foreign Policy'. Latin American Politics and Society 53: 1-24.

Manfield, Edward and Diana Mutz. 2009. 'Support for free trade: self-interest, Sociotropic Politics and Out-Group Anxiety'. International Organization 63, Summer: 425-57.

Pinheiro, Leticia. 2009. 'Autores y actores de la política exterior brasileña'. Foreign Affairs Latinoamérica 9 (2): 43-54.

Russell, Roberto and Juan Gabriel Tokatlian. 2002. 'El lugar del Brasil en la polítiica exterior de la Argentina: La visión del otro'. Revista Desarrollo Económico 42 (167): 405-428.

Risse-Kappen, Thomas. 1991. 'Public Opinion, Domestic Structure, and Foreign Policy in Liberal Democracies'. World Politics 43(4): 479-512.

Schirm, Stefan. 2010. 'Leaders in need of followers: emerging powers in global governance'. European Journal of International Relations 16 (2): 197-221.

Shapiro, Robert and Benjamin Page. 1988. 'Foreign Policy and the Rational Public'. The Journal of Conflict Resolution 32(2): 211-247.

Soares de Lima, Maria Regina. 2007. 'Brasil como país intermedio: imprecisión conceptual y dilemas políticos'. In Juan Gabriel Tokatlian (ed), India, Brasil y Sudáfrica: el impacto de las nuevas potencias regionales. Buenos Aires: Libros del Zorzal, pp.169-190. 


\section{Carola Lustig and Tomás Olego}

Stolper, Wolfgang Friedrich and Paul Samuelson. 1941. 'Protection and Real Wages'. Review of Economic Studies 9 (1): 58-73.

Tokatlian, Juan Gabriel. 2013. 'Cuán poderoso es Brasil?' Foreign Affairs Latinoamérica 13 (1): 25-30.

UTDT - UdeSA. 2015. 'El capítulo argentino del sondeo para Las Américas y el mundo'. Centro de Investigación y Docencia Económica, CAFDevelopment Bank of Latin America, Konrad Adenauer Foundation in Argentina and Vidanta Foundation.

\section{Appendix}

\section{Table A}

Metropolitan area by administrative circumscription

\begin{tabular}{|l|c|}
\hline DEPARTAMENTO & PLAZA \\
\hline GONFLUENCIA & Alto Valle \\
\hline CAPITAL & Alto Valle \\
COLON & Córdoba-Gran Córdoba \\
\hline BERISSO & Córdoba-Gran Córdoba \\
ENSENADA & Gran La Plata \\
LA PLATA & Gran La Plata \\
\hline CAPITAL & Gran La Plata \\
GODOY CRUZ & Gran Mendoza \\
GUAYMALLEN & Gran Mendoza \\
LAS HERAS & Gran Mendoza \\
LUJAN DE CUYO & Gran Mendoza \\
MAIPU & Gran Mendoza \\
\hline CAPITAL & Gran Mendoza \\
CRUZ ALTA & Gran Tucumán \\
TAFI VIEJO & Gran Tucumán \\
YERBA BUENA & Gran Tucumán \\
\hline LA CAPITAL & Gran Tucumán \\
PARANA & Paraná-Santa Fe \\
\hline CAPITAL & Paraná-Santa Fe \\
SAN FERNANDO & Resistencia-Corrientes \\
\hline
\end{tabular}

(to be continued) 
Public Opinion and Framing Effects of

Argentine Foreign Policy Toward Brazil...

Table A

Metropolitan area by administrative circumscription

\begin{tabular}{|c|c|}
\hline DEPARTAMENTO & PLAZA \\
\hline ALMIRANTE BROWN & RMBA \\
\hline AVELLANEDA & RMBA \\
\hline BERAZATEGUI & RMBA \\
\hline Comuna 01 & RMBA \\
\hline Comuna 02 & RMBA \\
\hline Comuna 03 & RMBA \\
\hline Comuna 04 & RMBA \\
\hline Comuna 05 & RMBA \\
\hline Comuna 06 & RMBA \\
\hline Comuna 07 & RMBA \\
\hline Comuna 08 & RMBA \\
\hline Comuna 09 & RMBA \\
\hline Comuna 10 & RMBA \\
\hline Comuna 11 & RMBA \\
\hline Comuna 12 & RMBA \\
\hline Comuna 13 & RMBA \\
\hline Comuna 14 & RMBA \\
\hline Comuna 15 & RMBA \\
\hline ESTEBAN ECHEVERRIA & RMBA \\
\hline EZEIZA & RMBA \\
\hline FLORENCIO VARELA & RMBA \\
\hline GENERAL SAN MARTIN & RMBA \\
\hline HURLINGHAM & RMBA \\
\hline ITUZAINGO & RMBA \\
\hline JOSE C PAZ & RMBA \\
\hline LA MATANZA & RMBA \\
\hline LANUS & RMBA \\
\hline LOMAS DE ZAMORA & RMBA \\
\hline MALVINAS ARGENTINAS & RMBA \\
\hline MERLO & RMBA \\
\hline MORENO & RMBA \\
\hline MORON & RMBA \\
\hline
\end{tabular}

(to be continued) 


\section{Carola Lustig and Tomás Olego}

Table A

Metropolitan area by administrative circumscription

\begin{tabular}{|l|c|}
\hline DEPARTAMENTO & PLAZA \\
\hline QUILMES & RMBA \\
SAN FERNANDO & RMBA \\
SAN ISIDRO & RMBA \\
SAN MIGUEL & RMBA \\
TIGRE & RMBA \\
TRES DE FEBRERO & RMBA \\
VICENTE LOPEZ & RMBA \\
\hline ROSARIO & Rosario-Gran Rosario \\
SAN LORENZO & Rosario-Gran Rosario \\
\hline ESCOBAR & Tercer cordón \\
GENERAL RODRIGUEZ & Tercer cordón \\
MARCOS PAZ & Tercer cordón \\
PILAR & Tercer cordón \\
PRESIDENTE PERON & Tercer cordón \\
SAN VICENTE & Tercer cordón \\
\hline
\end{tabular}

Notes

1. The research is conducted on a sample of general population and on an opinion survey of qualified informants and movers and shakers of society. In the case of the quantitative study to the general population, the methodology used is a systematic study of public opinion, with probabilistic sampling by area and multistage selection with quotient of age, gender, and the search for characteristics of education and socioeconomic setting. The sampling adequacy was developed on the basis of population levels of large, medium and small cities across the country, as detailed below. 1,639 surveys were made and 1,603 valid samples were taken. Leaders: 170 valid interviews. Sample of opinion leaders is composed of rations of academia, government officials, newspaper, trade, military, business and church.

2. Torcuato Di Tella University (UTDT) and the University of San Andrés, (UdeSA) in the framework of the regional project "The Americas and the World" coordinated by the Centre for Economic Research and Teaching (CIDE) in Mexico with the financial sponsorship of the CAF-Development Bank Latin America, the Konrad Adenauer Foundation in Argentina, Vidanta 


\section{Public Opinion and Framing Effects of Argentine Foreign Policy Toward Brazil...}

Foundation and coordinated by professors Juan Gabriel Tokatlián (UTDT) and Federico Meke (UdeSA) based on 1,030 cases nationwide in Argentina.

3. Gaines, Kuklinski and Quirk (2006) give an example of an experiment made in the USA to measure the level of racial segregation and the position in front of positive actions, by creating two groups each of whom were asked their views on positive actions and then by showing them pictures about Afro-Americans. The second group was asked the same questions, but the order was inverted. The authors of the experiment found that the mere mention of positive action increases the negative stereotype of Afro-Americans in the white population.

\section{About the Authors}

Carola Lustig holds a Bachelor's degree in Political Science from the University of Buenos Aires, Argentina, and a Master's degree in Latin American Studies from the University of Salamanca, Spain. She was accepted for the PhD program in Social Sciences in Pompeu Fabra University, Spain. She is Assistant Professor of International Politics in Latin America at the Catholic University of Argentina, and coordinates the area of Governmental Relations at the PASCAL Program of the University of San Martín, Argentina. She has also worked as legislative advisor of the International Relations Committee in the Argentine Senate. Her main subfields of studies are International Relations and Comparative Politics, with a focus on Discourse Analysis of Foreign Policy in comparative perspective in Latin America.

Tomás Olego holds a Bachelor's degree in Political Science from the University of Buenos Aires, Argentina, and a Master's degree in Statistics from the same university. He is a PhD student of the Social Sciences Program at the University of Buenos Aires. He coordinates the area of Statistics at the PASCAL Program of the University of San Martín, Argentina. He also serves as Assistant Professor of Investigation techniques in Social Sciences at the University of Buenos Aires. His main topic of study is methodology in Social Sciences. In particular, he is interested in the application of statistical learning and computational methods to survey studies and electoral prediction. 